\title{
PERLINDUNGAN HUKUM BAGI KONSUMEN TERHADAP PEMBONGKARAN RUMAH DAN SERTIFIKAT YANG TIDAK SELESAI DALAM PEMBELIAN RUMAH SECARA KREDIT (Studi Kasus Jual Beli Rumah Di Cikarang)
}

\author{
Tia Monica Ifana Putri \\ (Mahasiswa Program S1 Fakultas Hukum Universitas Tarumanagara) \\ (Email : tia_monica09@yahoo.com)
}

\section{A.M Tri Anggraini \\ (Corresponding Author)}

(Dosen Fakultas Hukum Univesitas Trisakti, Meraih Sarjana Hukum dari Fakultas Hukum Universitas Gajahmada (1988), Magister Hukum dari Fakultas Hukum Universitas Tarumanagara (1995), Doktor Ilmu Hukum dari Fakultas Hukum Universitas Indonesia (2003)

(Email : anggraini1601@gmail.com)

\begin{abstract}
Legal protection for consumers means all government efforts to ensure legal certainty to provide protection to its citizens so that their rights as a citizen is not violated, and for those who violate will be subject to sanctions in accordance with applicable regulations. consumer protection at this time can not be separated from trading activities, in trade activities such as housing construction is expected to create a balance of rights and obligations between business actors and consumers. but the housing scheme often involves some problems that can hurt the consumer housing industry, because there are still many developers who only seek profits as big as possible without thinking about the needs of consumers, with the rights of consumers who violated the need for legal protection and responsibility of the perpetrator business based on Article 19 UUPK. The research method used by the writer is normative research method supported by interview with resource person. A brief analysis of this journal is titled by the author. Conclusions and suggestions about the issues studied by the author.
\end{abstract}

Keywords: Legal Protection, Responsible, and Demolition of the house. 


\section{PENDAHULUAN}

\section{A. Latar Belakang}

Indonesia sebagai negara berkembang, pada saat ini sedang giatgiatnya melakukan pembangunan di segala bidang. Pembangunan di Indonesia dilaksanakan secara bertahap, berkesinambungan dan berjangka panjang. Pembangunan itu dilaksanakan secara menyeluruh, tidak hanya dilakukan di kota-kota besar tetapi juga di daerah perdesaan, semua hasil dari pelaksanaan pembangunan tadi, diharapkan dapat meningkatkan taraf hidup dan kesejahteraan seluruh masyarakat Indonesia. Dengan demikian apa yang menjadi tujuan pembangunan nasional yaitu masyarakat yang adil dan makmur serta mewujudkan kesejahteraan lahir dan batin bagi seluruh rakyat Indonesia akan terpenuhi.

Saat ini masyarakat mengalami perkembangan yang cukup besar dalam berbagai bidang yaitu bidang teknologi, industri, dan ekonomi. Dengan berkembangnya kemajuan industrial dan juga semakin sulitnya ekonomi masyarakat seringkali membawa dampak yang tidak baik dalam kehidupan masyarakat sehingga memerlukan penanganan serius, khususnya masalah perlindungan konsumen dan peranan hukum sangat penting dalam usaha melindungi hak-hak konsumen.

Pengertian konsumen tidak terbatas pada konsumen yang sifatnya perorangan, akan tetapi dapat pula yang sifatnya badan hukum atau perusahaan yang dikategorikan sebagai pengguna atau pemakai suatu sarana atau suatu fasilitas barang dan/atau jasa yang terakhir. Faktor utama yang seringkali menjadi kelemahan konsumen adalah tingkat kesadaran konsumen akan haknya masih rendah. ${ }^{1}$

Definisi yuridis formal dari istilah konsumen sebagai definisi yuridis formal ditemukan pada Undang-Undang Nomor 8 Tahun 1999

\footnotetext{
${ }^{1}$ Adrian Sutedi, Tanggung Jawab Produk Dalam Hukum Perlindungan Konsumen, Cetakan ke-1.(Bogor: Ghalia Indonesia, 2008), hal. 1.
} 
tentang Perlindungan Konsumen (selanjutnya disebut UUPK). Pasal 1 butir 2 UUPK menyatakan bahwa konsumen adalah "setiap orang pemakai barang/dan atau jasa yang tersedia dalam masyarakat, baik bagi kepentingan diri sendiri, keluarga, orang lain, maupun mahluk hidup lain dan tidak untuk diperdagangkan". Perlindungan hukum bagi konsumen dalam hukum bisnis perlu diperhatikan sebab konsumen adalah orang yang berkepentingan untuk menumbuhkembangkan sebuah perusahaan. Setiap konsumen yang telah memberikan kewajibannya untuk memperoleh barang atau jasa yang diinginkan, penting juga untuk memperoleh hak-haknya. Salah satu hak konsumen adalah memperoleh perlindungan dari para pengembang.

Perlindungan konsumen pada saat ini tidak dapat dipisahkan dari kegiatan perdagangan. Dalam kegiatan perdagangan ini diharapkan menimbulkan keseimbangan hak dan kewajiban antara pelaku usaha dan konsumen. Di Indonesia saat ini perlindungan konsumen mendapat perhatian yang cukup baik karena menyangkut aturan untuk menciptakan kesejahteraan.

Perlindungan terhadap konsumen dipandang secara material maupun formal makin terasa sangat penting, mengingat makin lajunya ilmu pengetahuan dan teknologi yang merupakan motor penggerak bagi produktivitas dan efisiensi produsen atas barang atau jasa yang dihasilkannya dalam rangka mencapai sasaran usaha. Dalam rangka mengejar dan mencapai kedua hal tersebut, akhirnya baik langsung maupun tidak langsung, konsumenlah yang pada umumnya akan merasakan dampaknya. Dengan demikian, upaya-upaya untuk memberikan perlindungan yang memadai terhadap kepentingan konsumen merupakan suatu hal yang penting dan mendesak untuk segera dicari solusinya, terutama di Indonesia, mengingat sedemikian 
kompleknya permasalahan yang menyangkut perlindungan konsumen, lebih-lebih mengenai jual beli perumahan. ${ }^{2}$

Secara umum dan mendasar hubungan antara produsen (perusahaan penghasil barang dan atau jasa) dan konsumen (pemakai akhir dari barang dan atau jasa untuk diri sendiri atau keluarganya) merupakan hubungan yang terus menerus atau berkesinambungan. Hubungan tersebut terjadi karena keduanya memang saling menghendaki dan mempunyai tingkat ketergantungan yang cukup tinggi antara yang satu dengan yang lainnya. Produsen sangat membutuhkan dan sangat bergantung atas dukungan konsumen sebagai pelanggan. Tanpa dukungan konsumen, tidak mungkin produsen dapat terjamin kelangsungan usahanya. ${ }^{3}$

Bagi para pihak yang terlibat dalam penjualan perumahan secara kredit akan mendapat perlindungan hukum apabila pihak tersebut mempunyai bukti tertulis dalam ikatan jual beli perumahan secara kredit. Jual beli adalah suatu perjanjian timbal balik antara pihak satu dengan pihak lainnya. Pihak yang satu menyerahkan hak milik atas suatu barang, pihak lainnya berjanji untuk membayar dengan harga yang terdiri atas sejumlah uang sebagai imbalan dari perolehan hak milik tersebut. ${ }^{4}$ Seseorang atau suatu badan yang memberikan kredit percaya bahwa menerima kredit di masa mendatang akan sanggup memenuhi segala sesuatu yang telah dijanjikan itu dapat berupa barang, uang atau jasa. ${ }^{5}$

Pemberian kredit yang dilakukan oleh pihak Bank kepada konsumen untuk membayar pembelian rumah atas dasar kepercayaan dan keyakinan bahwa konsumen yang akan menerima kredit itu mampu dan mau mengembalikan kredit yang telah diterimanya. Dari faktor

\footnotetext{
${ }^{2}$ Celina Tri Siwi Kristianti, Hukum Perlindungan Konsumen, (Jakarta: Sinar Grafika, 2011), hal. 5-6.

${ }^{3}$ Husni Syawali dan Neni SriImaniyati, Hukum Perlindungan Konsumen, (Bandung: Mandar Maju, 2002), hal.36.

${ }_{5}^{4}$ R. Subekti, Aneka Perjanjian, Cetakan ke-10. (Bandung: Citra Aditya Bakti,1995), hal.2.

5 Thomas Suyatmo, et.al., Dasar-dasar Pengkreditan, (Jakarta: Gramedia Pustaka Umum, 1999), hal. 40.
} 
kemampuan dan kemauan tersebut, tersimpul unsur keamanan (safety) dan sekaligus juga untuk keuntungan (profiability) dari suatu kredit. Kedua unsur tersebut saling berkaitan.

Banyaknya pembangunan perumahan oleh pengembang perumahan, seringkali malah menimbulkan beberapa permasalahan yang dapat merugikan konsumen industri perumahan, karena masih banyak pengembang yang hanya mencari keuntungan yang sebesar-besarnya tanpa mengindahkan kebutuhan konsumen, terutama pengembang perumahan dengan skala kecil dan bukan merupakan anggota organisasi pengembang perumahan. Merebaknya kasus dalam industri properti atau perumahan pada dasarnya diawali dengan adanya ketidaksesuaian antara apa yang tercantum dengan apa yang termuat dalam ikatan jual beli yang ditandatangani oleh konsumen. ${ }^{6}$ Hal itu yang menyebabkan banyak konsumen yang mengeluh dan mengadukan permasalahannya.

Jenis pengajuan konsumen perumahan, secara umum ada dua kelompok. Pertama, pengaduan sebagai akibat telah terjadi pelanggaran hak-hak individual konsumen perumahan. Seperti, mutu bangunan dibawah standar, ukuran luas dan bahkan hak konsumen lainnya seperti pembongkaran salah satu rumah milik konsumen yang sebenarnya merupakan hak konsumen tersebut. Kedua, pengaduan sebagai akibat pelanggaran hak-hak kolektif konsumen perumahan. Seperti, tidak dibangunnya prasarana, sarana dan utilitas umum, sertifikat, dan rumah fiktif. ${ }^{7}$

Akibat adanya ketidakseimbangan antara para pengembang dan konsumen, maka dibentuklah Undang-Undang Nomor 8 Tahun 1999 tentang Perlindungan Konsumen (yang selanjutnya disebut dengan UUPK). Pembentukan Undang-undang tentang perlindungan konsumen merupakan langkah awal yang bagus, yang dibuat pemerintah dalam

\footnotetext{
${ }^{6}$ Shidarta, Hukum Perlindungan Konsumen Indonesia, (Jakarta: Grasindo, 2000), hal. 69.

${ }^{7}$ Sudaryatmo, Hukum dan Advokasi Konsumen, (Bandung: Citra Aditya Bakti, 1999), hal. 41.
} 
rangka mengimplementasikan aspirasi masyarakat konsumen Indonesia. ${ }^{8}$ Perlindungan konsumen adalah segala upaya yang menjamin adanya kepastian hukum untuk memberi perlindungan kepada konsumen.

Dalam UU Nomor 8 Tahun 1999 tentang Perlindungan Konsumen memberikan kewajiban-kewajiban kepada pengembang dalam melakukan kegiatan usaha sehingga tidak menimbulkan kerugian pada konsumen. Kewajiban-kewajiban para pengembang ini secara tegas ditentukan dalam Pasal 7 Huruf (b) dan (d) UUPK, yang menyatakan bahwa "Pelaku usaha atau pengembang mempunyai kewajiban untuk memberikan informasi yang benar, jelas dan jujur mengenai kondisi, jaminan serta memberikan penjelasan penggunaan, perbaikan dan menjamin mutu barang dan jasa yang diproduksi atau diperdagangkan berdasarkan ketentuan standar yang berlaku”.

Selain itu UUPK juga bertujuan untuk menciptakan sistem perlindungan konsumen terkait hak dan kewajiban dalam perlindungan konsumen yang mengandung unsur kepastian hukum serta keterbukaan informasi sekaligus menumbuhkan kesadaran pengembang mengenai pentingnya perlindungan konsumen. ${ }^{9}$

Permasalahan perlindungan konsumen terkait hak-hak konsumen ini tidak akan pernah ada habisnya dan akan selalu menjadi suatu hal yang akan dibahas dalam masyarakat. Selama masih banyak hak dan kepentingan yang dilanggar hingga adanya pihak yang dirugikan, maka masalah terkait perlindungan konsumen tidak akan pernah bisa selesai. Meskipun telah adanya UUPK yang dibentuk untuk melindungi kepentingan konsumen, akan tetapi tetap saja pada kenyataannya yang terjadi di pasaran masih banyak pelanggaran terhadap ketentuan yang terdapat di dalam Undang-Undang Perlindungan Konsumen, seperti yang

\footnotetext{
${ }^{8}$ Endang Sri Wahyuni, Aspek Hukum Sertifikasi \& Keterkaitannya Dengan Perlindungan Konsumen, (Medan: PT. Citra Aditya bakti, 2003), hal. 90.

${ }^{9}$ Aman Sinaga, Pemberdayaan Hak-hak Konsumen di Indonesia, Edisi 1. (Jakarta Tim Penerbit Perlindungan Konsumen Direktorat Perlindungan Konsumen dan Yayasan Gemainti, 2001), hal. 52.
} 
ditemukan dalam kejadian pembongkaran rumah konsumen yang membuat konsumen merasa dirugikan.

Dalam UUPK Pasal 4 tercantum salah satu hak konsumen adalah "Hak untuk mendapatkan perlindungan dan upaya penyelesaian sengketa perlindungan konsumen secara patut, serta hak untuk mendapatkan kompensasi, ganti rugi dan/atau penggantian apabila barang dan/atau jasa yang diterima atau didapat tidak sesuai dengan perjanjian atau tidak sebagaimana mestinya".

Berdasarkan uraian latar belakang diatas, Penulis merasa tertarik untuk melakukan tinjauan lebih lanjut mengenai korelasi aturan dalam Undang-Undang Nomor 8 Tahun 1999 tentang Perlindungan Konsumen terhadap kasus jual beli rumah di Cikarang.

\section{B. Perumusan Masalah}

Berdasarkan pemaparan latar belakang yang telah diuraikan di atas, maka untuk lebih memfokuskan penelitian ini dirumuskan permasalahan sebagai berikut :

1. Bagaimana Perlindungan Hukum Bagi Konsumen Terhadap Pengembang Dan Pihak Bank Yang Tidak Memenuhi Kewajibannya Terhadap Konsumen?

2. Upaya Hukum Yang Dapat Dilakukan Konsumen Dalam Hal Terjadi Pembongkaran Rumah?

\section{Metode Analisis}

Metode penelitian hukum merupakan suatu proses untuk menemukan aturan hukum, prinsip-prinsip hukum, maupun doktrindoktrin hukum guna menjawab isu hukum yang akan dihadapi.

\section{Tipe Penelitian}

Tipe yang digunakan Penulis dalam penulisan ini yaitu metode penelitian hukum normatif. Menurut Peter Mahmud Marzuki, tidak 
perlu istilah penelitian hukum normatif, karena istilah legal research selalu normatif. Cukup dikemukakan bahwa penelitian ini adalah penelitian hukum, dengan pernyataan demikian sudah jelas bahwa penelitian tersebut bersifat normatif. ${ }^{10}$ Pada penelitian ini, Penulis menggunakan pendekatan Undang-Undang dan studi kasus. Pendekatan Undang-Undang adalah pendekatan yang dilakukan dengan menelaah semua Undang-Undang dan regulasi yang bersangkutan paut dengan isu hukum yang sedang ditangani ${ }^{11}$

\section{Jenis dan Sumber Data}

Metode Penelitian hukum normatif terdapat 3 (tiga) macam bahan pustaka yang dapat digunakan, yaitu:

a. Bahan Hukum Primer

Bahan hukum primer merupakan bahan hukum yang besifat autoritatif, artinya mempunyai otoritas ${ }^{12}$ bahan hukum primer yang digunakan dalam penulisan ini adalah Undang-Undang Nomor 8 Tahun 1999 tentang Perlindungan Konsumen, Undang-Undang Nomor 1 Tahun 2011 tentang Perumahan dan Kawasan Pemukiman.

b. Bahan Hukum Sekunder

Bahan hukum sekunder adalah bahan-bahan yang berupa semua publikasi tentang hukum yang bukan merupakan dokumen-dokumen resmi. ${ }^{13}$ Adapun bahan hukum sekunder yang digunakan dalam melakukan penelitian ini adalah literatur-literatur dalam kepustakaan hukum (buku-buku hukum) dan Perjanjian kredit serta salinan Akta Jual Beli yang berkaitan dengan judul yang dibahas oleh Penulis.

c. Bahan Non-Hukum

Bahan non hukum adalah merupakan bahan hukum sebagai pelengkap dari kedua bahan hukum dari jurnal non hukum seperti

\footnotetext{
${ }^{10}$ Peter Mahmud Marzuki, Penelitian Hukum Edisi Revisi, (Jakarta: Kencana Preneda Media Group, 2013), hal. 56.

${ }^{11}$ Ibid., hal. 133.

${ }^{12}$ Ibid., hal. 181.

${ }^{13}$ Ibid., hal. 190.
} 
Kamus Besar Bahasa Indonesia (KBBI) dan wawancara dengan narasumber.

\section{Teknik pengumpulan data}

Teknik pengumpulan data dalam penelitian hukum normatif dilakukan dengan cara studi kepustakaan, yang bersumber dari peraturan perundangundangan, buku-buku, Selain itu dilakukan wawancara kepada narasumber dengan menggunakan pedoman wawancara yang disusun secara sistematis guna menjawab atau menganalisis permasalahan yang ada.

\section{Teknik Pengolahan Data}

Pengelolaan data pada hakikatnya merupakan kegiatan untuk mengadakan analisis terhadap permasalahan yang akan diteliti. Dalam penelitian hukum normatif, pengolahan data dan bahan hukum berwujud kegiatan untuk mengadakan sistematisasi terhadap data dan bahan hukum tertulis dengan cara melakukan seleksi data sekunder dilanjutkan dengan kualifikasi dan menyusun data hasil penelitian tersebut secara sistematis dan logis. $^{14}$

\section{Teknik Analisa Data}

Teknik analisis data yang digunakan adalah teknik normatif kualitaitf yaitu proses menyusun secara sistematis data yang diperoleh dari hasil wawancara, data-data yang didapat dan mengkualifikasikan kemudian menghubungkan dengan teori yang berhubungan dan menarik kesimpulan untuk menentukan hasil pada penulisan Penulis.

\section{PEMBAHASAN}

\section{A. Kasus Posisi}

Kronologi kasus, Tanah yang terletak di daerah Cikarang Kabupaten Bekasi dengan Hak Milik Nomor 05/Sinar Jaya merupakan

\footnotetext{
${ }^{14}$ Ibid., hal. 180.
} 
lokasi atau objek (AJB) dibangunnya sebuah rumah diatas tanah seluas $\pm 72 \mathrm{~m}^{2}$ (tujuh puluh dua meter persegi).

Pada mulanya pembangunan perumahan dilakukan oleh pengembang PT X selaku investor di daerah Cikarang Kabupaten Bekasi, dengan nama Perumahan Bumi Cikarang Indah dengan satu (1) sertifikat induk, setelah ada pembeli di satu kavling, kemudian dipecah sertifikat menjadi beberapa sertifikat sesuai dengan kavling yang sudah laku.

Pemecahan sertifikat biasanya dilakukan oleh notaris untuk dibalik-nama dan diagunkan ke Bank, tetapi dalam kasus ini pemecahan sertifikat dilakukan oleh pengembang, yang mana hal tersebut tidak dijalankan oleh pengembang sehingga sertifikat tersebut belum bisa di balik nama dan diagunkan ke bank, sementara sudah ada AJB(Akta Jual Beli) oleh konsumen dan sudah mengagunkan berdasarkan surat yang ada saat ini.

Dalam kasus ini pada mulanya pembangunan proyek tersebut semua berjalan lancar dan bahkan hampir sebagian rumah yang sudah dibangun sudah laku dan telah dihuni, dan pembelian rumah oleh konsumen di perumahan tersebut hampir seluruhnya menggunakan fasilitas pembiayaan pembelian rumah oleh pihak Bank berdasarkan hak tanggungan.

Berdasarkan AJB yang ada, sudah disepakati antara seorang pelaku usaha pembangunan rumah bernama Andi Anwar dan seorang konsumen bernama Bronson Nainggolan yang dibuat di hadapan notaris dan PPAT Evy Ferdiana pada tanggal 22 Juni 2009 jelas dikatakan bahwa harga telah di sepakati sebesar Rp.49.500.000,- (empat puluh sembilan juta lima ratus ribu rupiah), dimana pembiayaan yang dilakukan oleh konsumen sesuai Pasal 1 dalam AJB ini adalah melalui proses Kredit Pemilikan Rumah (KPR) pada Bank A dengan menandatangani Perjanjian Kredit.

Penandatanganan KPR oleh konsumen dilakukan dalam hari yang sama ketika AJB ditandatangani, Pada Hari Senin, tanggal 22 Juni 2009. 
Di dalam perjanjian tersebut, konsumen menyetujui ketentuan-ketentuan didlaam perjanjian kredit tersebut sebagaimana cicilan perbulan dibayarkan sejumlah Rp. 590.000 (lima ratus sembilan puluh ribu rupiah) dengan jatuh tempo setiap tanggal 7 setiap bulannya. Dalam AJB juga di sebutkan bahwa objek jual beli tersebut tidak tersangkut dalam suatu sengketa, bebas dari sitaan, tidak terikat jaminan untuk sesuatu utang yang tidak tercatat dalam sertifikat, dan bebas dari beban-beban lainnya yang berupa apapun.

Namun beberapa tahun belakangan mulai terjadi permasalahan internal dalam PT X yang mengakibatkan kerugian, sehingga proyek pembangunan tersebut dialihkan kepada PT Y, dimana PT Y akan melanjutkan pembangunan rumah tersebut.

Pada saat proses pembangunan yang dilakukan oleh PT Y, terdapat satu Blok didalam kawasan perumahan tersebut yang di bongkar secara sepihak, Setelah dilakukannya pembongkaran tersebut terdapat beberapa rumah yang ternyata masih dalam proses cicilan KPR (Kredit Pembelian Rumah) oleh satu bank yang prosesnya berjalan lancar tanpa ada tunggakan, yang mana rumah tersebut adalah salah satu rumah milik konsumen yang dirugikan dan tindakan oleh PT Y selaku pengembangini yang menyebabkan kerugian pada debitur yang mempunyai salah satu rumah tersebut. Konsumen merasa dirugikan dan tidak mendapatkan haknya sebagai konsumen atas rumah tersebut, hal ini yang termasuk melanggar hak-hak konsumen dalam Undang-Undang Nomor 8 Tahun 1999 tentan Perlindungan Konsumen, seringkali konsumen menanyakan kejelasan dan tanggung jawab ganti rugi kepada pihak bank maupun pihak pengembang atas haknya terhadap pembongkaran serta proses sertifikat rumah tersebut namun belum adanya tindakan lebih lanjut dari pihak bank maupun pihak pengembang. 


\section{B. Analisa}

\section{Perlindungan Hukum Bagi Konsumen Terhadap Pengembang} Dan Pihak Bank Yang Tidak Memenuhi Kewajibannya

\section{Terhadap Konsumen}

Dapat diuraikan terlebih dahulu beberapa tahapan sesuai proses atau prosedur pindah tangan/ peralihan hak dari pelaku usaha ke konsumen sebagai berikut:

a. Tahap Pra Transaksi

Yang dimaksud dengan tahap pra transaksi adalah tahap sebelum adanya perjanjian/transaksi konsumen, yaitu keadaan atau peristiwa yang terjadi sebelum konsumen memutuskan untuk membeli produk barang dan/atau jasa produsen sebagai pelaku usaha. Pada tahap ini, sesuai dengan haknya sebagai konsumen, konsumen mencoba mencari informasi mengenai kebutuhannya, antara lain syarat-syarat yang perlu di penuhi atau disediakan, harga, komposisi, kegunaan, cara pemakaian dan sebagainya, informasi ini dapa diperoleh langsung dari produsen pelaku usaha penjualan rumah maupun melalui marketing perumahan dalam bentuk iklan, dan lain-lain, pada tahap ini marketing perumahan menggunakan brosur dalam penjualan rumah, tahap inilah yang merupakan tahap penentuan pilihan dari konsumen dan konsumen diharuskan lebih teliti dan cermat;

b. Tahap Transaksi

Pada tahap transaksi telah terjadi kesepakatan antara konsumen dengan pelaku usaha, terjadinya peralihan barang dan atau jasa yaitu bisa dengan perjanjian tertulis maupun lisan, dalam kasus diatas peralihan hak berdasarkan AJB antara pelaku usaha dengan konsumen. Pada tahap inilah disepakati apa yang 
menjadi hak dan kewajiban para pihak, termasuk cara pembayarannya. Dalam kasus diatas menggunakan kredit pada Bank dengan menggunakan sistem KPR. Konsumen akan mendapatkan denda sebesar $1,50 \%$ per bulan jika tidak dapat melunasi angsuran pada Bank setiap tanggal jatuh tempo yaitu setiap tanggal 7 setiap bulannya. Hal tersebut sudah dilakukan dengan baik oleh konsumen tanpa adanya tunggakan, namun rumah konsumen dibongkar tanpa adanya konfirmasi sama sekali oleh pihak pengembang/pelaku usaha dan sertifikat rumah tidak terselesaikan. Hal ini juga memberikan asumsi bahwa pengembang tidak ada itikad baik dalam menjalankan usahanya.

Bentuk perlindungan hukum terhadap konsumen terbagi dua yaitu Perlindungan Hukum Preventif, yakni bentuk perlindungan hukum dimana kepada rakyat diberi kesempatan untuk mengajukan keberatan atau pendapatnya sebelum suatu keputusan pemerintah mendapat bentuk yang definitif, Sedangkan Perlindungan Hukum Represif, yakni bentuk perlindungan hukum dimana lebih ditujukan dalam penyelesaian sengketa. Mengingat masalah ini telah terjadi, maka upaya hukum represiflah yang dapat dilakukan konsumen. Apabila pengembang atau pelaku usaha tidak bertanggungjawab terhadap perrbuatannya tersebut, maka konsumen dapat menempuh jalur hukum dengan mengajukan gugatan terhadap pelaku usaha sesuai dengan peraturan perundang-undangan yang mengatur mengenai perbuatan tersebut, yakni KUHPerdata, UUPK, dan Peraturan-peraturan hukum yang terkait.

Menurut pembentuk UUPK, Perlindungan konsumen diartikan sebagai upaya yang menjamin adanya kepastian hukum untuk memberikan perlindungan hukum terhadap konsumen, pada dasarnya bertujuan untuk meningkatkan harkat dan martabat konsumen. Guna mencapai tujuan tersebut maka 
Undang-Undang menerapkan dua strategi yaitu melalui upaya pemberdayaan konsumen (meningkatkan pengetahuan, kesadaran, kepedulian, kemampuan dan kemandirian konsumen untuk melindungi dirinya sendiri). Upaya lainnya yaitu mendorong terciptanya iklim usaha yang sehat agar menumbuhkan rasa tanggung jawab bagi pelaku usaha. Cara tersebut adalah upaya dari UUPK untuk menciptakan keseimbangan perlindungan antara konsumen dan pelaku usaha. Pembentuk UUPK menetapkan beberapa asas yang diatur pada Pasal 2 UUPK dan tujuan dari perlindungan konsumen diatur dalam Pasal 3 UUPK. Hak dan kewajiban konsumen diatur dalam Pasal 4 dan Pasal 5 dimana dalam kasus ini konsumen sudah memenuhi kewajibannya namun tidak memperoleh haknya karena perbuatan pelaku usaha yang membongkar rumah secara sepihak. Pelaku usaha dalam kasus ini tidak menjalankan usahanya dengan itikad baik, dan tidak menjalankan kewajibannya sesuai dengan Pasal 7 UUPK. Seharusnya pelaku usaha bertanggungjawab mengganti kerugian pada konsumen yang telah mengalami kerugian, Pasal 19 Bentuk ganti rugi yang diberikan tidak selalu berupa uang tetapi dapat berupa penggantian barang/jasa yang sejenis atau setara.

Prinsip tanggung jawab merupakan perihal yang sangat penting dalam hukum perlindungan konsumen. Dalam kasuskasus pelanggaran hak konsumen, diperlukan kehati-hatian dalam menganalisis siapa yang harus bertanggung jawab dan seberapa jauh tanggung jawab dapat dibebankan kepada pihakpihak terkait.

Secara umum, prinsip-prinsip tanggung jawab dalam hukum dapat dibedakan menjadi $:^{15}$ 65.

${ }^{15}$ Shidarta, Hukum Perlindungan Konsumen Indonesia, (Jakarta: Grasindo, 2000), hal. 59- 
1) Kesalahan ( Liability based on fault)

Prinsip tanggung jawab berdasarkan unsur kesalahan adalah prinsip yang cukup umum berlaku dalam hukum pidana maupun perdata. Prinsip ini menyatakan, seorang baru dapat dimintakan pertanggungjawabannya secara hukum jika ada unsur kesalahan yang digunakannya.

2) Praduga selalu bertanggung jawab (Presumption of liability) Prinsip ini menyatakan, tergugat selalu dianggap bertanggung jawab, sampai ia dapat membuktikan ia tidak bersalah, jadi beban pembuktian ada pada tergugat.

3) Praduga selalu tidak bertanggung jawab (Presumption of non liablity)

Prinsip ini hanya dikenal dalam lingkup transaksi konsumen yang sangat terbatas. Contohnya dari penerapan prinsip ini adalah pada pengangkutan, kehilangan atau kerusakan pada bagasi kabin/bagasi tangan, yang dibawa oleh konsumen adalah tanggung jawab dari konsumen.

4) Tanggung jawab mutlak (stricy liability)

Ada beberapa pendapat ahli yang mengatakan bahwa tanggung jawab mutlak adalah prinsip tanggung jawab yang menetapkan kesalahan tidak sebagai faktor yang menentukan. Namun, ada pengecualian yang memungkinkan untuk dibebaskan dari tanggung jawab.

5) Pembatasan tanggung jawab (limitation of liability)

Prinsip pembatasan tanggung jawab dengan pembatasan sangat disenangi oleh pelaku usaha untuk dicantumkan dalam klausula eksonerasi dalam perjanjian standar yang dibuatnya.

Dua prinsip penting dalam UUPK yang diakomodasi adalah tanggung jawab produk dan tanggung jawab professional. Kedua permasalahan tersebut sebenarnya terdapat pada prinsip-prinsip tanggung jawab, tetapi dibahas terpisah karena perlu diberikan penguraian tersendiri. Tanggung jawab produk sebenarnya mengacu pada tanggung jawab para produsen untuk produk yang dibawanya kedalam peredaran, yang menimbulkan atau menyebabkan kerugian karena cacat yang melekat pada produk tersebut. Sementara tanggung jawab professional berkaitan dengan tanggung jawab terhadap jasa professional yang diberikan kepada klien. Sumber persoalan dalam tanggung jawab 
profssional dapat timbul karena penyedia jasa professional tidak memenuhi perjanjian yang mereka sepakati dengan klien mereka.

Pada prinsipnya perlindungan terhadap kerugian konsumen telah dijamin oleh Undang-undang namun terkadang penerapanya di lapangan tidak sesuai dengan dasar hukum serta prinsip-prinsip yang telah diatur oleh Undang-undang baik itu dalam Undangundang Nomor 8 Tahun 1999 tentang Perlindungan Konsumen, Kitab Undang-undang Hukum Perdata dan beberapa teori hukum di Indonesia. Dengan adanya peraturan hukum mengenai pelaku usaha dan konsumen, maka apa yang menjadi hak dan kewajiban konsumen serta pelaku usaha dan bagaimana tanggung jawab yang harus dilakukan pelaku usaha dapat diketahui oleh konsumen serta pelaku usaha. Hal itu tentu memudahkan konsumen dalam melakukan pembelaan terkait hak-haknya yang telah dilanggar oleh pelaku usaha, dan pelaku usaha juga mengetahui sejauh apa kewajiban serta tanggung jawab mereka terhadap produk atau barang dan jasa yang mereka jual terkait kegiatan usahanya.

Dalam hal jual beli antara penjual dan pembeli keduanya harus mengedepankan itikad baik, hal itu yang akan memudahkan konsumen serta pelaku usaha terkait adanya sengketa atas kerugian konsumen, karena kebanyakan pelaku usaha akan berkelit dan lari dari tanggung jawab. Seharusnya pembeli/konsumen mendapatkan ganti rugi sesuai dengan yang diatur dalam Undang-Undang, pembeli hanya menginginkan ganti rugi baik berupa pengantian biaya yang telah dikeluarkan untuk membeli sebuah rumah, jika tidak ada pengembalian biaya, minimal lakukan upaya lain untuk mengembalikan hak-hak konsumen yang dirugikan. Sampai saat ini, belum ada tindakan yang dilakukan pengembang dan pihak Bank atas masalah ini. 
Jika dilihat dari prinsip perlindungan konsumen, masalah ini tidak sesuai dengan prinsip The Privity Of Contract, dimana dalam prinsip ini menyatakan bahwa pelaku usaha mempunyai kewajiban untuk melindungi konsumen, hal itu baru dapat dilakukan jika diantara mereka telah terjalin suatu hubungan kontraktual. Adanya AJB merupakan bukti dari adanya kesepakatan jual beli antara pelaku usaha dengan konsumen. Walaupun secara yuridis sering dinyatakan, antara pelaku usaha dan konsumen berkedudukan sama, tetapi faktanya konsumen adalah pihak yang biasanya selalu didikte menurut kemauan si pelaku usaha. Fenomena kontrak-kontrak standar yang banyak beredar di masyarakat merupakan petunjuk yang jelas betapa tidak berdayanya konsumen mengahadapi dominasi pelaku usaha. Dalam kotrak demikian si pelaku usaha dapat menghilangkan kewajiban yang seharusnya dipikulnya.

\section{Upaya Hukum Yang Dapat Dilakukan Konsumen Dalam Hal Terjadi Pembongkaran Rumah}

Dalam suatu perjanjian, suatu hal yang sangat penting diperhatikan adalah masalah penafsiran perjanjian, tidak selamanya perjanjian atau kesepakatan dilaksanakan sama seperti yang dikehendaki oleh para pihak. Jika hal tersebut terjadi, besar kemungkinan pemenuhan hak dan kewajiban sebagaimana dimaksudkan semula akan menghadapi kendala yang pada akhirnya akan melahirkan konflik atau sengketa, tahap inilah yang disebut dengan Tahapan Pasca Transaksi. pihak yang merasa dirugikan biasanya akan melakukan suatu usaha untuk mendapatkan haknya kembali jika terjadi sesuatu hal yang tidak diinginkan yang dapat merugikan salah satu pihak yang merasa dirugikan. Usaha tersebut dikenal dengan sebutan upaya hukum suatu upaya yang dilakukan sesuai dengan prosedur hukum yang berlaku di Negara 
Indonesia, ada bebarapa upaya hukum yang dapat dilakukan oleh konsumen yaitu sebagai berikut:

1. Pengaduan/ Complain

Dalam hal perlindungan konsumen apabila terjadi suatu sengketa, dalam UUPK telah diatur mengenai penyelesaian sengketa yang terdapat dalam Pasal 45. ${ }^{16}$ Dalam pasal ini disebutkan sebagai berikut:

a. Setiap konsumen yang dirugikan dapat menggugat pelaku usaha melalui lembaga yang bertugas menyelesaikan sengketa antara konsumen dan pelaku usaha atau melalui peradilan yang berada di lingkungan peradilan umum;

b. Penyelesaian sengketa konsumen dapat ditempuh melalui pengadilan atau di luar pengadilan berdasarkan pilihan sukarela para pihak yang bersengketa;

c. Penyelesaian sengketa di luar pengadilan sebagaimana dimaksud pada ayat (2) tidak menghilangkan tanggungjawab pidana sebagaimana diatur dalam Undang-undang;

d. Apabila telah dipilih upaya penyelesaian sengketa konsumen di luar pengadilan, gugatan melalui pengadilan hanya dapat ditempuh apabila upaya tersebut dinyatakan tidak berhasil oleh salah satu pihak atau oleh para pihak.

2. Penyelesaian Sengketa melalui BPSK

Tujuan BPSK untuk penyelesaian sengketa konsumen di luar pengadilan (Pasal 49 Ayat (1) UUPK) melalui cara mediasi atau konsiliasi yang anggotanya terdiri dari unsur:

a. Pemerintah;

b. Lembaga Konsumen;

c. Pelaku Usaha.

Penyelesaian sengketa konsumen melaui cara mediasi dan konsiliasi memberikan kewenangan yang lebih besar kepada para

\footnotetext{
${ }^{16}$ Pasal 45 UUPK, hal. 3.
} 
pihak untuk menyelesaikan dan menemukan sendiri penyelesaian masalahnya. Sedangkan lembaga, baik mediator dan konsiliator sebagai pihak ketiga yang dilibatkan dalam penyelesaian sengketa konsuen oleh para pihak, bersifat netral dan tidak berwenang untuk memutus. $^{17}$

Berdasarkan UUPK Pasal 52 menyebutkan bahwa tugas dan wewenang BPSK meliputi: ${ }^{18}$

1) Melaksanakan penanganan dan penyelesaian sengketa konsumen, dengan cara melalui mediasi atau arbitrase atau konsiliasi;

2) Memberikan konsultasi perlindungan konsumen;

3) Melakukan pengawasan terhadap pencantuman klausula baku;

4) Melaporkan kepada penyidik umum apabila terjadi pelanggaran ketentuan dalam undang-undang ini;

5) Menerima pengaduan baik tertulis maupun tidak tertulis, dari konsumen tentang terjadinya pelanggaran terhadap perlindungan konsumen;

6) Melakukan penelitian dan pemeriksaan sengketa perlindungan konsumen;

7) Memanggil pelaku usaha yang diduga telah melakukan pelanggaran terhadap perlindungan konsumen;

8) Memanggil dan menghadirkan saksi, saksi ahli dan/atau setiap orang yang dianggap mengetahui pelanggaran terhadap undang-undang ini;

9) Meminta bantuan penyidik untuk menghadirkan pelaku usaha, saksi, saksi ahli, atau setiap orang sebagaimana dimaksud pada angka (7) dan (8), yang tidak bersedia memenuhi panggilan badan penyelesaian sengketa konsumen;

10) Mendapatkan, meneliti dan/atau menilai surat, dokumen, atau alat bukti lain guna penyelidikan dan/atau pemeriksaan;

11) Memutuskan dan menetapkan ada atau tidak adanya kerugian di pihak konsumen;

12) Memberitahukan putusan kepada pelaku usaha yang melakukan pelanggaran terhadap perlindungan konsumen;

13) Menjatuhkan sanksi administratif kepada pelaku usaha yang melanggar ketentuan undang-undang ini.

${ }^{17}$ Munir Fuady, Arbitrase Nasional Alternatif Penyelesaian Sengketa Bisnis, (Bandung: PT Citra Aditya Bakti, 2000), hal. 33-55.

${ }^{18}$ Susanti Adi Nugroho, Proses Penyelesaian Sengketa Konsumen Ditinjau Dari Hukum Acara Serta Kendala Implementasinya, Cetakan Ke-2. (Jakarta: kencana, 2008), hal. 421. 
Prosedur Penyelesaian Sengketa melalui BPSK yaitu BPSK membentuk majelis dengan jumlah anggota berjumlah ganjil yang terdiri dari sedikitnya tiga orang yang mewakili semua unsur, dan dibantu seorang panitera. Dalam hal ini BPSK diwajibkan untuk menyelesaikan sengketa konsumen dalam jangka waktu 21 hari terhitung sejak gugatan diterima oleh BPSK. Penyelesaian sengketa melalui BPSK ini dikhususkan bagi konsumen perorangan yang memiliki perselisihan dengan pelaku usaha dengan sifat penyelesaian yang cepat dan murah.

3. Penyelesaian Sengketa melalui Pengadilan

a. Prosedur

Di pengadilan, penyelesaian perkara dimulai dengan mengajukan gugatan ke pengadilan yang berwenang. Penyelesaian sengketa hukum melalui pengadilan ini dilakukan dengan 3 tahap. Tahap permulaan dengan mengajukan gugatan sampai dengan jawab jinawab. Tahap penentuan dimulai dari pembuktian sampai dengan putusan, dan tahap pelaksanaan adalah pelaksanaan putusan. Setiap tahap tersebut memerlukan waktu relatif lama, mahal dan prosedur yang cukup rumit.

b. Upaya hukum di pengadilan

Walaupun putusan yang dijatuhkan majelis BPSK bersifat final dan mengikat, para pihak yang tidak setuju atas putusan tersebut dapat mengajukan keberatan kepada pengadilan negeri untuk diputus dalam waktu 21 hari dengan waktu 14 hari untuk mengajukan kebertan ke pengadilan negeri. Terhadap putusan pengadilan negeri ini dapat diajukan upaya hukum kasasi ke Mahkamah Agung RI yang akan diputus dalam waktu 30 hari, dengan waktu 14 hari untuk mengajukan kasasi, selain itu penyelesaiannya bisa juga dengan menggunakan lembaga penyelesaian perkara kecil dan sederhana atau yang disebut 
dengan lembaga Small Claim Court. Secara umum, berdasarkan Perma Nomor 2 Tahun 2015 tentang Tata Cara Penyelesaian Gugatan Sederhana yang biasa disebut dengan Small Claim Court dipergunakan untuk menyebut sebuah lembaga penyelesaian perkara perdata berskla kecil dengan cara sederhana, tidak formal, cepat dan biaya murah. Dilihat dari sanksi administrasi berupa penetapan ganti kerugian paling banyak sebesar Rp 200.000.000 (dua ratus juta rupiah), yang dapat dibebankan dkepada pelaku usaha. Dalam kasus diatas, konsumen tidak membawa permasalahan ini ke jalur hukum maupun BPSK dikarenakan sudah ada pilihan hukum pada saat itu yang sudah disepakati oleh konsumen dan pengembang untuk meneyelesaikan masalahnya sendiri, tetapi sampai saat ini tidak ada itikad baik dari pengembang.

Dalam kasus yang terjadi antara pihak pengembang (PT.X) dengan pembelinya yang merasa dirugikan atas pembongkaran rumah di daerah Cikarang, Kabupaten Bekasi dengan nama Perumahan Bumi Cikarang Indah dan sertifikat yang tidak selesai, pasti melakukan berbagai upaya untuk menuntut haknya kembali. Berbagai upaya telah dilakukan oleh konsumen untuk mendapatkan haknya kembali. Konsumen menginginkan ganti rugi yang pantas untuk konsumen yang sudah memenuhi kewajiban yang ditandatangani dalam Akta Jual Beli dan dalam Perjanjian Kredit.

Upaya yang telah dilakukan antara lain :

1. Dimulai dari meninjau langsung perkembangan atas rumah yang telah dibongkar yang sampai saat ini tidak ada perkembangan lebih lanjut;

2. Mengirimkan pesan tertulis kepada pihak Pengembang dan Pihak Bank; 
3. Bertanya langsung untuk meminta pertanggungjawaban pihak pengembang maupun pihak Bank tetapi hanya janji-janji saja yang diberikan oleh pihak bank tetapi hal itu tidak terlaksana.

Upaya-upaya yang dilakukan oleh konsumen tersebut rupanya hanyalah sia-sia. Tidak ada tanggapan serius dari pihak pengembang maupun pihak Bank. Tidak ada kata musyawarah dalam persoalan ini. Pihak pengembang selalu berusaha menghindari konsumen yang ingin berkonfirmasi seputar hal tersebut yang dapat memungkinkan pihak pengembang mengupaya memberi ganti rugi kepada konsumen.

Dalam kasus Perumahan Bumi Cikarang Indah, pihak PT.X selaku pengembang yang jelas telah melakukan perbuatan lalai, yakni tidak dapat memenuhi prestasinya sehingga menyebabkan salah satu rumah milik konsumen dibongkar dengan tidak beralasan. Apabila pengembang memang tidak dapat menyanggupi kewajibannya sebagai pelaku usaha, pengembang wajib bertanggung jawab pada pihak pembeli. Oleh karena itu pengembang sebaiknya melakukan penyelesaian dengan cara baikbaik.

\section{PENUTUP}

\section{A. Kesimpulan}

Berdasarkan uraian analisis yang telah penulis uraikan diatas, maka dapat ditarik kesimpulan bahwa Bentuk perlindungan hukum terhadap konsumen diatur secara detail dalam UUPK yaitu Perlindungan Hukum Preventif dan Perlindungan Hukum Represif. Perlindungan Hukum Preventif yakni bentuk perlindungan hukum dimana kepada rakyat diberi kesempatan untuk mengajukan keberatan atau pendapatnya sebelum suatu keputusan pemerintah mendapat bentuk yang definitif, Sedangkan Perlindungan Hukum Represif, yakni bentuk perlindungan hukum 
dimana lebih ditujukan dalam penyelesaian sengketa. Mengingat masalah ini telah terjadi, maka upaya hukum represiflah yang dapat dilakukan konsumen. Apabila pengembang atau pelaku usaha tidak bertanggungjawab terhadap perrbuatannya tersebut, maka konsumen dapat menempuh jalur hukum dengan mengajukan gugatan terhadap pelaku usaha sesuai dengan peraturan perundang-undangan yang mengatur mengenai perbuatan tersebut, yakni KUHPerdata, UUPK, dan Peraturan-peraturan hukum yang terkait. Menurut pembentuk UUPK, Perlindungan konsumen diartikan sebagai upaya yang menjamin adanya kepastian hukum untuk memberikan perlindungan hukum terhadap konsumen, pada dasarnya bertujuan untuk meningkatkan harkat dan martabat konsumen. Guna mencapai tujuan tersebut maka UndangUndang menerapkan dua strategi yaitu melalui upaya pemberdayaan konsumen (meningkatkan pengetahuan, kesadaran, kepedulian, kemampuan dan kemandirian konsumen untuk melindungi dirinya sendiri). Upaya lainnya yaitu mendorong terciptanya iklim usaha yang sehat agar menumbuhkan rasa tanggung jawab bagi pelaku usaha. Cara tersebut adalah upaya dari UUPK untuk menciptakan keseimbangan perlindungan antara konsumen dan pelaku usaha. Pembentuk UUPK menetapkan beberapa asas yang diatur pada Pasal 2 UUPK dan tujuan dari perlindungan konsumen diatur dalam Pasal 3 UUPK. Hak dan kewajiban konsumen diatur dalam Pasal 4 dan Pasal 5 dimana dalam kasus ini konsumen sudah memenuhi kewajibannya namun tidak memperoleh haknya karena perbuatan pelaku usaha yang membongkar rumah secara sepihak. Dengan adanya hak-hak konsumen yang dilanggar maka pelaku usaa harus bertanggungjawab sesuai dengan isi Pasal 19 UUPK . Bentuk ganti rugi yang diberikan tidak selalu berupa uang tetapi dapat berupa penggantian barang/jasa yang sejenis atau setara.

\section{B. Saran}

1. Bagi pihak pengembang dan pihak Bank penyelenggara KPR, haruslah lebih memahami, memperhatikan dan melakukan 
kewajibannya dalam jual beli perumahan sehingga nantinya akan mendapatkan haknya secara baik juga dan sebaiknya menyediakan dan menanggapi pengaduan bagi nasabah/konsumen yang dirugikan dalam pembelian rumah, terutama dalam hal memberikan ganti rugi.

2. Bagi konsumen, hendaknya lebih berhati-hati dalam memilih pelaku usaha pembangunan perumahan supaya melihat pengalaman dan kredibilitas pelaku usaha terlebih dahulu, dan hrus berani complain dan melakukan upaya hukum untuk mengembalikan hak-haknya sebagai konsumen.

\section{Daftar Pustaka}

Fuady, Munir, Arbitrase Nasional Alternatif Penyelesaian Sengketa Bisnis. (Bandung: PT Citra Aditya Bakti, 2000).

Kristianti, Celina Tri Siwi, Hukum Perlindungan Konsumen. (Jakarta: Sinar Grafika, 2011).

Marzuki, Peter Mahmud, Penelitian Hukum Edisi Revisi, (Jakarta: Kencana Preneda Media Group, 2013).

Nugroho, Susanti Adi, Proses Penyelesaian Sengketa Konsumen Ditinjau Dari Hukum Acara Serta Kendala Implementasinya. (Jakarta: kencana, 2008).

Shidarta, Hukum Perlindungan Konsumen Indonesia. (Jakarta: Grasindo, 2000).

Sinaga, Aman, Pemberdayaan Hak-hak Konsumen di Indonesia. (Jakarta: Tim Penerbit Perlindungan Konsumen Direktorat Perlindungan Konsumen dan Yayasan Gemainti, 2001).

Subekti, R., Aneka Perjanjian. (Bandung: Citra Aditya Bakti,1995).

Sudaryatmo, Hukum dan Advokasi Konsumen. (Bandung :Citra Aditya Bakti, 1999).

Sutedi, Adrian, Tanggung Jawab Produk Dalam Hukum Perlindungan Konsumen. (Bogor: Ghalia Indonesia, 2008).

Suyatmo, Thomas, et. al., Dasar-dasar Pengkreditan. (Jakarta: Gramedia Pustaka Umum,1999). 
Tia Monica Ifana Putri \& A.M Tri Anggraini

Perlindungan Hukum Bagi Konsumen Terhadap Pembongkaran Rumah Dan Sertifikat Yang Tidak Selesai Dalam Pembelian Rumah Secara Kredit (Studi Kasus Jual Beli Rumah Di Cikarang)

Syawali Husni dan neni SriImaniyati, Hukum Perlindungan Konsumen. (Bandung: Mandar Maju, 2002).

Wahyuni, Endang Sri, Aspek Hukum Sertifikasi \& Keterkaitannya Dengan Perlindungan Konsumen. (Medan: PT. Citra Aditya bakti, 2003). 